\title{
Heteroannelation of Cyclic Ketones: Synthesis, Characterization and Antitumor Evaluation of Some Condensed Azine Derivatives
}

\author{
Essam A. Soylem, Mohammed G. Assy and Ghania M. Morsi* \\ Department of Chemistry, Faculty of Science, Zagazig University, Egypt \\ * Corresponding author: E-mail: ghaniamohammed@yahoo.com
}

Received: 27-01-2016

\begin{abstract}
A series of pyrimidine and thiazine derivatives was synthesized by one-pot reaction of cyclopentanone with a mixture of an aromatic aldehyde, namely $o$-anisaldehyde, and different ureas, namely urea, guanidine and thiourea, respectively. Furthermore, cycloaddition reaction of active methylene reagents, namely acetyl acetone, malononitrile, ethyl cyanoacetate, cyanoacetamide and $N$-phenyl cyanoacetamide with 2,6-bis(2-methoxybenzylidene)cyclohexanone afforded chromene and quinoline derivatives in basic medium. The antitumor evaluation of some new compounds against three human cell lines, namely MCF-7, NCI-H460 and SF-268 showed significant and moderate activity compared with the positive control doxorubicin.
\end{abstract}

Keywords: Cyclopentapyrimidine, Thiazolopyrimidine, Quinazoline, Chromene, Antitumor activity

\section{Introduction}

The azines have been reported to have antibacterial, ${ }^{1,2}$ analgesic, ${ }^{3}$ antitubercular, ${ }^{4,5}$ anti-inflammatory, ${ }^{6,7}$ antioxidant, ${ }^{8,9}$ and antiviral activities. ${ }^{11-14}$ 2-Oxo-1,2dihydropyridine-3-carbonitrile derivatives were reported as inhibitors of the oncogenic serine/threonine kinase ${ }^{15,16}$ and for the treatment of the congestive heart failure. ${ }^{17,18}$

Cycloalkanones, such as cyclopentanone and cyclohexanone, react cleanly with urea or thiourea and aromatic aldehydes to give three families of fused heterobicyclic, benzylidene heterobicyclic, and spiro heterotricyclic pyrimidines as key intermediates for the preparations of many biologically active compounds. ${ }^{19-28}$ The modification, however, is still able to maintain the active moiety of the compound.

In view of these observations and due to our recent interest in developing novel multicomponent reactions (MCRs) for heterocyclic synthesis via dipolar intermediates, ${ }^{29-39}$ we report herein the synthesis of some new derivatives of condensed pyrimidines of cycloalkanone and aldehyde bearing ortho effect with nitrogen nucleophiles and preliminarily evaluate their anticancer properties.

Furthermore, reaction of 2,6-bis(2-methoxybenzylidene)cyclohexanone (6) with different cyano nucleophi- les yielded chromene and quinoline derivatives of promising antitumor activity.

\section{Results and Discussion}

\section{1. Chemistry}

The goal of this work was to study the possibility of azine synthesis by [3+3] cycloaddition of $\alpha, \beta$-unsaturated systems to diverse nucleophiles, to afford condensed pyrimidine and pyridine ring systems. These compounds are readily available in high yields under the conditions of both acidic and basic catalysis. Thus, one-pot three component reaction of $o$-anisaldehyde, guanidine sulphate and cyclopentanone in a basic medium resulted in a Michaeltype adduct that was identified as the cyclic product $\mathbf{1}$ (Scheme 1).

The ${ }^{1} \mathrm{H}$ NMR spectrum of $\mathbf{1}$ exhibited three singlets at $\delta 10.25-8.60\left(\mathrm{D}_{2} \mathrm{O}\right.$ exchangeable $)$ corresponding to the guanidine protons and a singlet at $5.65 \mathrm{ppm}$ belonging to the $\mathrm{CH}$ methylenic group. ${ }^{13} \mathrm{C}$ NMR of $\mathbf{1}$ was in agreement with the expected structure that can exist in equilibrium with its non isolable tautomers. On the other hand, acid induced [3+3] cycloaddition of cyclopentanone, anisaldehyde and urea afforded cyclopentapyrimidine derivati- 


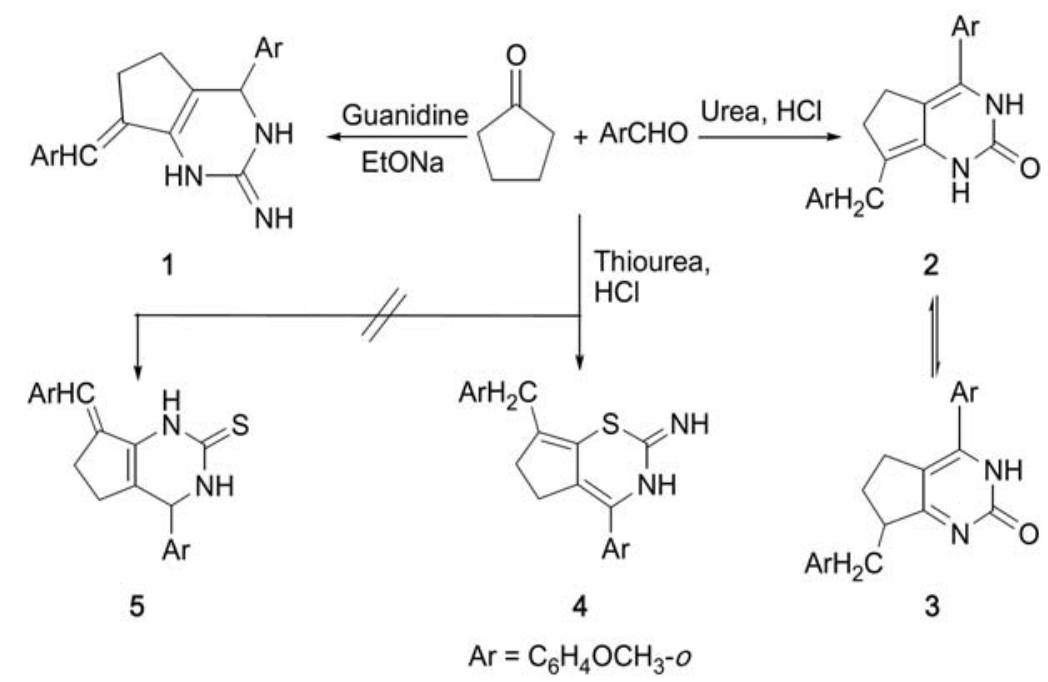

Scheme 1. One pot synthesis of cyclopenta[ $d]$ pyrimidines $\mathbf{1}, \mathbf{2}, \mathbf{3}$ and cyclopenta[ $e][1,3]$ thiazine $\mathbf{4}$ derivatives.

ves $\mathbf{2}$ and $\mathbf{3}$ (in ratio 1:1) as shown in Scheme 1. The structures of the latter products were established on the basis of analytical and spectral data. Thus, the ${ }^{1} \mathrm{H}$ NMR spectrum of 2 showed two singlets at $\delta 11.81$ and $9.98\left(\mathrm{D}_{2} \mathrm{O}\right.$ exchangeable) corresponding to the two $\mathrm{NH}$ groups and a singlet at $\delta 3.80 \mathrm{ppm}$ indicating $\mathrm{CH}_{2}$ benzylic group. The ${ }^{1} \mathrm{H}$ NMR spectrum of $\mathbf{3}$ showed a multiplet at $\delta 5.40$, a triplet at 3.75 and a multiplet at $\delta 3.64-2.65 \mathrm{ppm}$ corresponding to $\mathrm{CH}$ methylenic, $\mathrm{CH}_{2}$ benzylic groups and $\mathrm{CH}_{2}$ of cyclopentane, respectively.

The three-components Biginelli-like reaction of $o$ anisaldehyde, cyclopentanone and thiourea in an acidic medium resulted in heterocyclization potentiated by the more reactive $\mathrm{SH}$ than $\mathrm{NH}$ group (i.e. kinetic product) ${ }^{40}$ affording thiazine derivative $\mathbf{4}$ and none of the pyrimidine derivative 5 was obtained (Scheme 1). The structure of $\mathbf{4}$ was established from its analytical and spectral data.
Thus, the ${ }^{1} \mathrm{H}$ NMR spectrum of $\mathbf{4}$ showed two singlets at $\delta$ 10.00 and $9.94\left(\mathrm{D}_{2} \mathrm{O}\right.$ exchangeable) corresponding to two $\mathrm{NH}$ groups and a singlet at $3.91 \mathrm{ppm}$ indicating $\mathrm{CH}_{2}$ of benzyl group.

Formation of the pyrimidinones $\mathbf{2}, \mathbf{3}$ and thiazinimine 4 from cyclopentanone, $o$-anisaldehyde, urea and/or thiourea presumably proceeds via the formation of acyclic Michael-type adducts of 2,5-bis(2-methoxybenzylidene)cyclopentanone, followed by the heterocyclization and a series of hydrogen shifts with the subsequent isomerization in the case of urea cycloaddition as shown in Scheme 2.

Furthermore, synthesis of pyrimidine thione 7 was achieved via a base induced [3+3] cycloaddition of thiourea and $\alpha, \beta$-unsaturated system $\mathbf{6}$ as shown in Scheme 3. ${ }^{1} \mathrm{H}$ NMR spectrum of 7 showed two singlets at $\delta 9.13$ and 8.69 corresponding to $\mathrm{NH}$ groups and a singlet at $\delta 5.18$ ppm corresponding to the $\mathrm{CH}$ methylenic proton. Com-

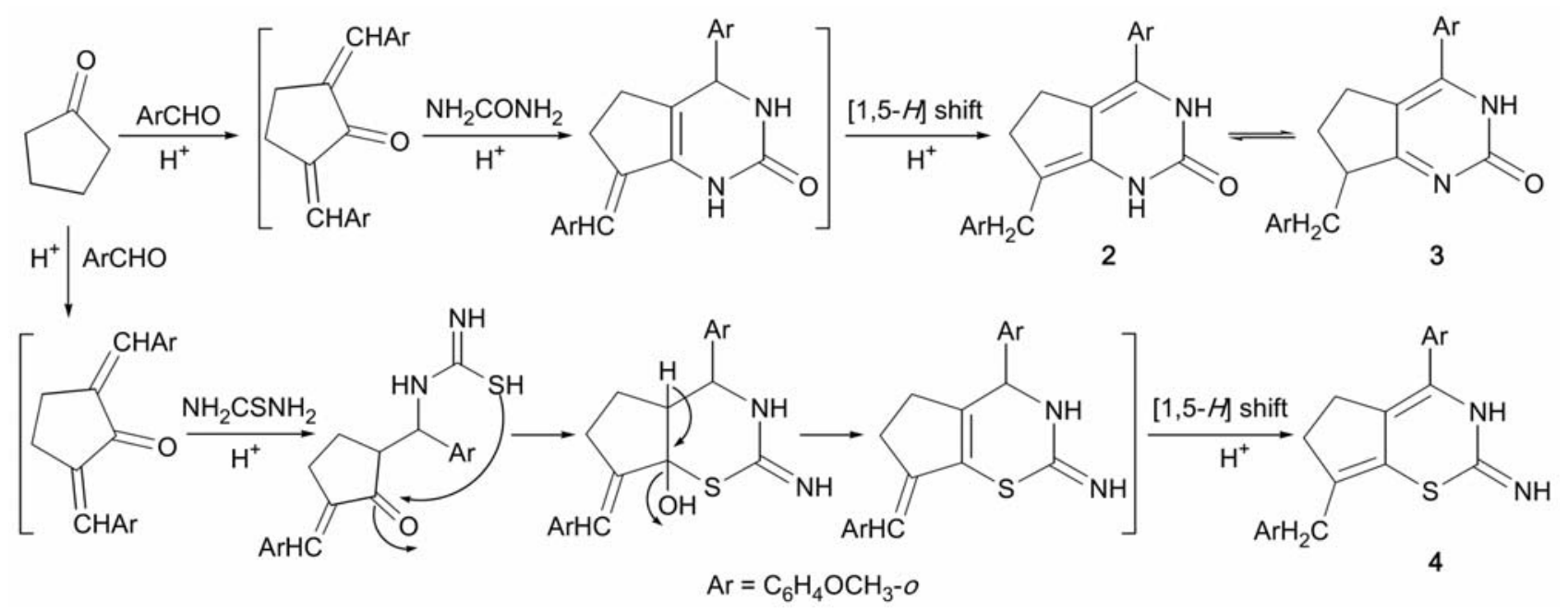

Scheme 2. Postulated mechanism for the formation of cyclopenta[ $d]$ pyrimidin-2-ones $\mathbf{2 , 3}$ and cyclopenta[e][1,3]thiazin-2(3H)-imine $\mathbf{4}$ derivatives. 
pound 7 was reacted with $\mathrm{H}_{2} \mathrm{O}_{2}$ in the presence of $\mathrm{NaOH}$ to produce the oxidized product that was identified as the pyrimidinone 8 . Whereas using $\mathrm{H}_{2} \mathrm{O}_{2}$ in acetic acid as the oxidizing agent resulted dehydrogenation, in addition to the desulfurization, afforded the quinazoline derivative of type 9 . Also, the pyrimidine thione 7 was allowed to react with hydrazine hydrate in dry pyridine resulting in the hydrazinolysis in addition to the basic isomerization producing the final product $\mathbf{1 0}$ (Scheme 3 ).

The structures of the latter products were established on the basis of analytical and spectral data. The IR spectrum of 8 revealed a peak at $1671 \mathrm{~cm}^{-1}$ of the carbonyl group and ${ }^{1} \mathrm{H}$ NMR spectrum showed a singlet at $\delta$ $8.07 \mathrm{ppm}$ corresponding to the NH group. ${ }^{1} \mathrm{H}$ NMR spectrum of 9 showed a multiplet at $\delta 8.20-6.96$ ppm corresponding to the aromatic and ethylenic protons. The ${ }^{1} \mathrm{H}$ NMR of the hydrazino derivative $\mathbf{1 0}$ showed two singlets at $\delta 9.13$ and $8.68\left(\mathrm{D}_{2} \mathrm{O}\right.$ exchangeable $)$ corresponding to $\mathrm{NH}$ groups, a singlet at $5.18\left(\mathrm{D}_{2} \mathrm{O}\right.$ exchangeable) belonging to the $\mathrm{NH}_{2}$ group and a singlet at $3.84 \mathrm{ppm}$ indicating $\mathrm{CH}_{2}$ benzylic protons.

Curiously, $\alpha, \beta$-unsaturated system of the type $\mathbf{6}$ underwent intermolecular cycloaddition with 2-amino-1,3thiazol-4 $(5 H)$-one to produce thiazolopyrimidine derivative $\mathbf{1 1}$ potentiated by the high nucleophilicity of the ring nitrogen than the enolic tautomer of thiazolone, therefore none of the chromenothiazole $\mathbf{1 2}$ was obtained (Scheme $3)$. The analytical and spectral data were consistent with the proposed structure. Thus, the IR spectrum of $\mathbf{1 1}$ revealed a peak at $1696 \mathrm{~cm}^{-1}$ of the carbonyl group and the ${ }^{1} \mathrm{H}$ NMR spectrum showed double doublet at $\delta 4.14$ corresponding to the $\mathrm{CH}_{2}$ group of thiazole, a singlet at $\delta$ 4.50 indicating $\mathrm{CH}$ methylenic and a multiplet at $\delta$ 7.95-6.93 ppm corresponding to Ar-H and $\mathrm{CH}$ ethylenic group.

Upon the reaction of $o$-anisalcyclohexanone $\mathbf{6}$ with acetyl acetone (AcAc) a cycloaddition took place forming chromene derivative, which in turn underwent a hydrogen shift giving the final product 13. None of the naphthalene derivative 14 was obtained due to the enolic tautomer of the intermediate adduct facilitating the attack of the enolic $\mathrm{OH}$ to the acetyl carbonyl under the reaction conditions to produce the desired chromene $\mathbf{1 3}$ (Scheme 4). The analytical and spectral data were consistent with the proposed structure. Thus, the IR spectrum of $\mathbf{1 3}$ revealed a peak at $1660 \mathrm{~cm}^{-1}$ of the carbonyl group and the ${ }^{1} \mathrm{H}$ NMR spectrum showed a singlet at $\delta 3.88$ indicating the $\mathrm{CH}_{2}$ benzylic group, a singlet at $\delta 2.49$ corresponding to the acetyl protons and a singlet at $\delta 2.46 \mathrm{ppm}$ belonging to methyl protons.

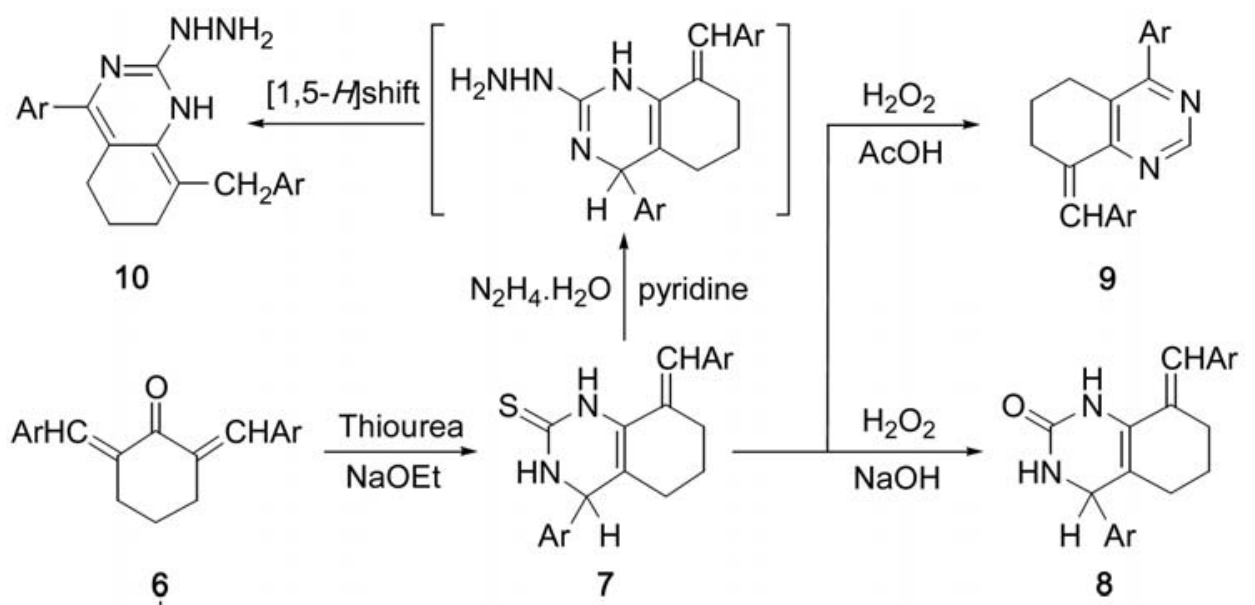<smiles>O=C1CSC2=NC(Br)C3=C(C(=C[Al])CCC3)N2C1=O</smiles>

11 one

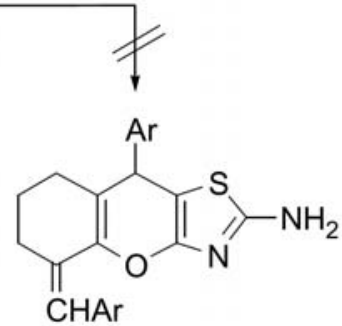

12

$$
\mathrm{Ar}=\mathrm{C}_{6} \mathrm{H}_{4} \mathrm{OCH}_{3}-\mathrm{O}
$$

Scheme 3. The synthetic route for cycloaddition of $\alpha, \beta$-unsaturated cyclic ketone. 
The high yield of $\alpha, \beta$-unsaturated system of the type 6 encouraged us to study their further reactivity towards cyanomethylene reagents. Thus, malononitrile added its nucleophilic carbon to the electrophilic carbon of 6 producing acyclic Michael-type adduct 15 that intramolecularly cyclizes producing chromene-3-carbonitrile of the type 16. While, $\alpha, \beta$-unsaturated system 6 when allowed to react with ethyl cyanoacetate afforded chromene-3-carbonitrile of the type 17. None of the products 18 and 19 were obtained. Concerning the proposed mechanism, we expected that attack of the enolic $\mathrm{OH}$ to the ester carbonyl, which is more electrophilic than the cyano carbon, leads to the formation of chromene-3-carbonitrile 17 (Scheme 4). The analytical and spectral data of the obtained products were in agreement with the assigned structures. Thus, the ${ }^{1} \mathrm{H}$ NMR spectrum of $\mathbf{1 7}$ (as an example) showed beside the expected signals of the cyclohexane moiety, two singlets at $\delta 3.83$ and $3.78 \mathrm{ppm}$ corresponding to the two $\mathrm{CH}$ groups, a multiplet at $\delta$ 7.80-6.97 ppm including the aromatic protons with $\mathrm{CH}$ ethylenic groups and the IR spectrum exhibited peaks at
2197 and $1674 \mathrm{~cm}^{-1}$ of the cyano and carbonyl groups, respectively.

Also, cyanoacetamide produced the Michael-type adduct $\mathbf{2 0}$ upon its reaction with ketonic compound $\mathbf{6}$ followed by basic isomerization giving the final quinoline product 21. The IR spectrum of $\mathbf{2 1}$ revealed a peak at 2223 $\mathrm{cm}^{-1}$ of the $\mathrm{CN}$ group and the ${ }^{1} \mathrm{H}$ NMR spectrum showed a singlet at $\delta 12.05$ according to $\mathrm{NH}$ group and doublet at $\delta 3.71 \mathrm{ppm}$ indicating the $\mathrm{Ar}-\mathrm{C}_{2}$ protons.

Finally, reaction of 2-cyano- $N$-phenylacetamide with the chalcone $\mathbf{6}$ in a basic medium afforded the intermediate product $\mathbf{2 2}$ which in turn underwent basic hydrolysis producing quinoline derivative $\mathbf{2 3}$ (Scheme 4). This reaction presumably proceeds via Michael addition followed by an intramolecular cyclization and subsequent Dimroth rearrangement affording 22 which in turn underwent basic hydrolysis producing quinoline derivative $\mathbf{2 3}$ (Scheme 5). The analytical and spectral data were consistent with the proposed structure.

Thus, the IR spectrum of $\mathbf{2 3}$ revealed peaks at 3432 for the acidic $\mathrm{OH}$ (broad) and $1707-1628 \mathrm{~cm}^{-1}$ characteri-<smiles>CCC1CCCC2C1=CC(=O)C(C(C)=O)=C2Br</smiles>

14<smiles>C=C1CCCC2=C1OC(=O)C(C#N)C2[Al]</smiles><smiles>[3H]C(=O)O[N+](=O)[O-]</smiles>

6<smiles>C=C1CCCC2=C1OC(N)=C(C(=O)OCC)C2Br</smiles>

18<smiles>C=C1CCCc2c1[nH]c(=O)c(C(=O)OCC)c2Br</smiles>

19

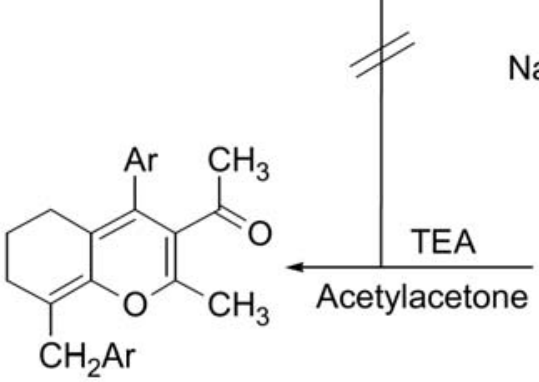

13

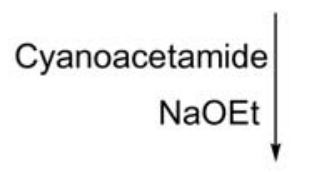

$\underset{\mathrm{TEA}}{\stackrel{\text { malononitrile }}{\longrightarrow}}$

$\mathrm{CHAr}$

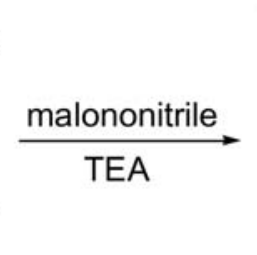

N-pheny
NaOEt

20<smiles>O=C1NC2=C(CCC(=CBr)C2)C(Br)C1C(=O)Nc1ccccc1</smiles>

22<smiles>C=C1C2=C(CCC1C)C(Br)C(C#N)=C(N)OC2=C([Al])[Al]</smiles>

15
16

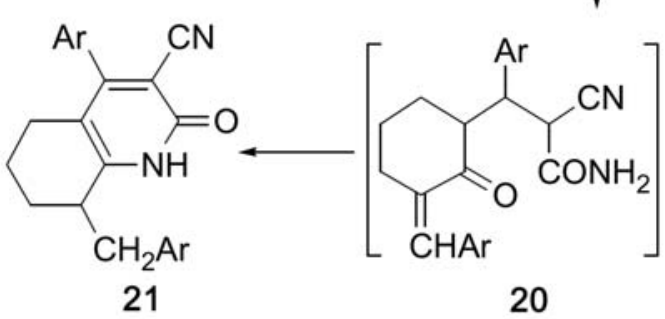

$\mathrm{Ar}=\mathrm{C}_{6} \mathrm{H}_{4} \mathrm{OCH}_{3}-\mathrm{O}$

Scheme 4. Condensation reactions of $\alpha, \beta$-unsaturated cyclic ketones with active methylene reagents. 


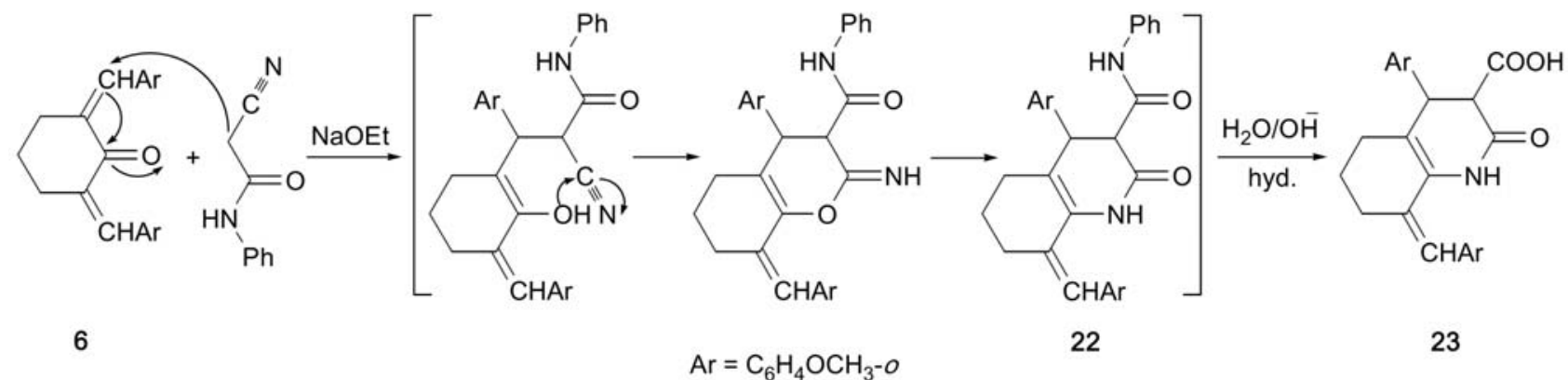

Scheme 5. Mechanism for the formation of product 23.

stic for the carbonyl groups. The ${ }^{1} \mathrm{H}$ NMR spectrum showed a multiplet at $\delta 7.56-6.88$ corresponding to the Ar-H and $\mathrm{CH}$ ethylenic, a singlet at $\delta 9.52\left(\mathrm{D}_{2} \mathrm{O}\right.$ exchangeable $)$ indicating the $\mathrm{NH}$ group and a singlet at $\delta 12.11 \mathrm{ppm}$ belonging to the carboxylic proton, in addition to the expected signals of the cyclohexane moiety.

\section{2. Antitumor Activity}

\section{2. 1. Tumor Cell Growth Assay}

The effects of compounds 1, 13, 16, 17 and/or 21 on the in vitro growth of human tumor cell lines were evaluated according to the procedure adopted by the National Cancer Institute (NCI, USA) in the 'In vitro Anticancer Drug Discovery Screen' that uses the protein-binding dye sulforhodamine B to assess cell growth. ${ }^{41,42}$ Briefly, exponentially, cells growing in 96-well plates were then exposed for $48 \mathrm{~h}$ to five serial concentrations of each compound, starting from a maximum concentration of 150 $\mu \mathrm{M}$. Following this exposure period adherent cells were fixed, washed, and stained. The bound stain was solublized and the absorbance was measured at $492 \mathrm{~nm}$ in a plate reader (Bio-Tek Instruments Inc., Power wave XS, Winooski, USA). For each test compound and cell line, a dose-response curve was obtained and the growth inhibition of $50 \%\left(\mathrm{GI}_{50}\right)$, corresponding to the concentration of the compounds that inhibited $50 \%$ of the net cell growth was calculated as described elsewhere. ${ }^{43}$ Doxorubicin was used as a positive control and tested in the same manner. For our newly synthesized products we selected the three cancer cell lines: the breast adenocarcinoma (MCF-7), non-small cell lung cancer (NCI-H460) and CNS cancer (SF-268) as our compounds are electron rich systems substituted with electronegative groups and many reports from previous work used such cell lines together with the use of doxorubicin which was showed to be the best positive control against the three cell lines (Table 1).

Results are given in concentrations that were able to cause $50 \%$ of cell growth inhibition $\left(\mathrm{GI}_{50}\right)$ after a continuous exposure of $48 \mathrm{~h}$ and show means \pm SEM of three independent experiments performed in duplicate.

\section{2. 2. Structure Activity Relationship (SAR)}

The compound 16 with $-\mathrm{CN}$ substitution at C-3 position of chromene ring and $-\mathrm{NH}_{2}$ substitution at C-2 position exhibited potent antitumor activity in MCF-7, NCIH460 and significant effect in SF-268. Also, compound 17 with $-\mathrm{CN}$ substitution at C-3 position of chromen-2-one ring exhibited potent antitumor activity in SF-268, NCIH460 and significant effect in MCF-7. However, compound 13 with $-\mathrm{COCH}_{3}$ substitution at $\mathrm{C}-3$ position of chromene moiety as well as $-\mathrm{CH}_{3}$ substitution at C-2 position showed significant effect in MCF-7 and moderate activity in both NCI-H460 and SF-268. On the other hand, 2-oxoquinolinecarbonitrile 21 with - $\mathrm{CN}$ substitution at $\mathrm{C}-3$ position was the lowest in both. Comparing the antitumor activity of the tested compounds and their analogous described in the literature, ${ }^{37-38}$ it is obvious that the highest cytotoxicity might be attributed to the presence of

Table 1. Effect of compounds 1, 13, 16, 17 and 21 on the growth of three human tumor cell lines

\begin{tabular}{cccc}
\hline Compound & \multicolumn{3}{c}{ GI $_{\mathbf{5 0}}(\boldsymbol{\mu M})(\%$ growth $)$} \\
\hline $\mathbf{1}$ & MCF-7 & NCI-H460 & SF-268 \\
$\mathbf{1 3}$ & $20.23 \pm 4.50$ & $18.28 \pm 4.21$ & $42.62 \pm 4.80$ \\
$\mathbf{1 6}$ & $14.27 \pm 6.07$ & $18.15 \pm 4.05$ & $20.27 \pm 2.40$ \\
$\mathbf{1 7}$ & $4.16 \pm 1.09$ & $7.25 \pm 1.30$ & $12.80 \pm 3.90$ \\
$\mathbf{2 1}$ & $13.48 \pm 4.22$ & $6.09 \pm 1.88$ & $4.62 \pm 1.12$ \\
Doxorubicin & $22.31 \pm 3.40$ & $18.29 \pm 2.40$ & $28.11 \pm 10.30$ \\
& $0.04 \pm 0.008$ & $0.09 \pm 0.008$ & $0.09 \pm 0.007$ \\
\hline
\end{tabular}


the cyanoaminochromene and cyanochromen-2-one moiety bearing $2-\mathrm{CH}_{3} \mathrm{OC}_{6} \mathrm{H}_{4}$ group.

\section{Experimental}

\section{1. Chemistry}

All melting points were determined using a Stuart melting point apparatus by the open capillary tube method and are uncorrected. IR spectra were recorded on a Perkin-Elmer model $1600 \mathrm{FT}-\mathrm{IR}$ instrument as $\mathrm{KBr}$ pellets. ${ }^{1} \mathrm{H}$ and ${ }^{13} \mathrm{C}$ NMR spectra were recorded on a Varian $300 \mathrm{MHz}$ in DMSO- $d_{6}$ as solvent, using TMS as internal standard and chemical shifts are expressed as $\delta \mathrm{ppm}$. Antitumor activity and elemental analyses were performed by the Micro Analytical Center, Cairo University, Egypt. The starting material 6 was prepared as described in the literature. ${ }^{44}$ The progress of the reaction and the purity of the compounds were routinely monitored on TLC by pre-coated aluminum silica gel $60 \mathrm{~F}_{254}$ thin layer plates obtained from Merck (Germany) eluting with petroleum ether/ethyl acetate. The yields of all products were not optimized. All reagents used were obtained from commercial sources. All solvents were of analytical grade and used without further purification.

7-(2-Methoxybenzylidene)-4-(2-methoxyphenyl)-1,3, 4,5,6,7-hexahydro- $2 H$-cyclopenta $[d]$ pyrimidin-2-imine (1)

A mixture of $o$-anisaldehyde $(2.72 \mathrm{~g}, 0.02 \mathrm{~mol})$, cyclopentanone $(0.8 \mathrm{~g}, 0.01 \mathrm{~mol})$ and guanidine sulphate $(1.57 \mathrm{~g}$, $0.01 \mathrm{~mol}$ ) in $50 \mathrm{~mL}$ ethoxide solution [prepared by dissolving $\mathrm{Na}(0.92 \mathrm{~g}, 0.04 \mathrm{~mol})$ in $50 \mathrm{~mL}$ absolute ethanol] was heated under reflux for $5 \mathrm{~h}$. The reaction mixture was cooled, poured onto crushed ice and neutralized with acetic acid. The separated solid was filtered off, dried and recrystallized from acetic acid.

Yield: $78 \%$; m.p.: $258-260{ }^{\circ} \mathrm{C}$; IR $\left(\mathrm{KBr}, \mathrm{cm}^{-1}\right)$ : $3434(\mathrm{NH}), 2925,2856\left(\mathrm{CH}\right.$ aliphatic), $1635(\mathrm{C}=\mathrm{N}) ;{ }^{1} \mathrm{H}$ NMR $\left(300 \mathrm{MHz}, \mathrm{DMSO}-d_{6}\right): \delta 10.25,9.85,8.60(\mathrm{~s}, 3 \mathrm{H}$, $3 \mathrm{NH}$ ), 7.82-6.90 (m, 9H, Ar-H + CH ethylenic), 5.65 (s, $1 \mathrm{H}, \mathrm{Ar}-\underline{\mathrm{CH}}), 3.85,3.78\left(\mathrm{~s}, 6 \mathrm{H}, 2 \mathrm{OCH}_{3}\right), 3.17-2.85(\mathrm{~m}$, $4 \mathrm{H}, \mathrm{CH}_{2}$ cyclopentane); ${ }^{13} \mathrm{C}$ NMR (100 MHz, DMSO- $d_{6}$ ): $\delta 26.59,28.28,28.92,29.32,51.49,55.78,55.86,55.98$, 56.21, 111.44, 111.61, 111.84, 112.06, 115.96, 116.23, $118.35,118.80,119.35,119.55,119.63,119.66,120.09$, $120.36,120.57,120.74,120.84,121.00,121.36,122.92$, $124.07,125.52,125.87,127.42,128.12,128.27,128.45$, $128.61,128.97,129.09,129.64,129.91,129.97,130.25$, $130.45,131.43,132.37,133.19,136.92,138.24,138.90$, $140.29,152.77,156.66,156.72,156.84,156.95,157.87$, 157.95, 160.79, 160.83, 161.00, 161.28, 171.40, 195.79. Anal. Calcd. for $\mathrm{C}_{22} \mathrm{H}_{23} \mathrm{~N}_{3} \mathrm{O}_{2}$ (361.43): C, 73.11; H, 6.41; N, 11.63. Found: C, 73.05; H, 6.17; N, 11.56 .

General Procedure for the Synthesis of Compounds 2, 3 and 4
A mixture of $o$-anisaldehyde $(2.72 \mathrm{~g}, 0.02 \mathrm{~mol})$, cyclopentanone $(0.8 \mathrm{~g}, 0.01 \mathrm{~mol})$ with $0.60 \mathrm{~g}$ urea and/or $0.76 \mathrm{~g}$ thiourea $(0.01 \mathrm{~mol})$, and conc. $\mathrm{HCl}(0.03 \mathrm{~mol})$ in ethanol $(30 \mathrm{~mL})$ was heated under reflux for $5 \mathrm{~h}$. The reaction mixture was cooled and poured into ice cold water. The precipitated solid was filtered off, dried and recrystallized from the proper solvent to give the products 2,3 and $\mathbf{4}$, respectively.

7-(2-Methoxybenzyl)-4-(2-methoxyphenyl)-1,3,5,6-tetrahydro-2H-cyclopenta[ $d]$ pyrimidin-2-one (2). Yield: $40 \%$ from benzene; m.p.: $240-242{ }^{\circ} \mathrm{C}$; IR $\left(\mathrm{KBr}, \mathrm{cm}^{-1}\right)$ : $3414(\mathrm{NH}), 2924,2854$ (CH aliphatic), $1626(\mathrm{C}=\mathrm{O}) ;{ }^{1} \mathrm{H}$ NMR (300 MHz, DMSO- $\left.d_{6}\right): \delta 11.81,9.98(\mathrm{~s}, 2 \mathrm{H}, 2 \mathrm{NH})$, 7.86-6.92 (m, 8H, Ar-H), 3.87, 3.82 (s, 6H, 20CH ${ }_{3}$ ), 3.80 (s, $\left.2 \mathrm{H}, \mathrm{Ar}-\mathrm{CH}_{2}\right), 3.04,2.62$ (m, $4 \mathrm{H}, 2 \mathrm{CH}_{2}$ cyclopentane). Anal. Calcd. for $\mathrm{C}_{22} \mathrm{H}_{22} \mathrm{~N}_{2} \mathrm{O}_{3}(362.42) ; \mathrm{C}, 72.91 ; \mathrm{H}, 6.12$; N, 7.73. Found: C, 73.22; H, 5.82; N, 7.33.

7-(2-Methoxybenzyl)-4-(2-methoxyphenyl)-1,5,6,7tetrahydro-2H-cyclopenta $[d]$ pyrimidin-2-one $(3)$. Yield: $45 \%$ from methanol; m.p.: $200-202{ }^{\circ} \mathrm{C}$; IR (KBr, $\left.\mathrm{cm}^{-1}\right): 3408(\mathrm{NH}), 3076(\mathrm{CH}$ aromatic), 2930, $2854(\mathrm{CH}$ aliphatic) 1646 (C=O amide); ${ }^{1} \mathrm{H}$ NMR $(300 \mathrm{MHz}, \mathrm{DM}-$ SO- $\left.d_{6}\right): \delta 9.95(\mathrm{~s}, 1 \mathrm{H}, \mathrm{NH}), 7.87-6.80(\mathrm{~m}, 8 \mathrm{H}, \mathrm{Ar}-\mathrm{H}), 5.40$ $(\mathrm{m}, 1 \mathrm{H}, \mathrm{Ar}-\underline{\mathrm{CH}}), 3.87,3.82\left(\mathrm{~s}, 6 \mathrm{H}, 2 \mathrm{OCH}_{3}\right), 3.75(\mathrm{t}, 2 \mathrm{H}, J$ $\left.=10.2 \mathrm{~Hz}, \mathrm{Ar}-\mathrm{CH}_{2}\right), 3.64-2.65\left(\mathrm{~m}, 4 \mathrm{H}, 2 \mathrm{CH}_{2}\right.$ cyclopentane). Anal. Calcd. for $\mathrm{C}_{22} \mathrm{H}_{22} \mathrm{~N}_{2} \mathrm{O}_{3}(362.42): \mathrm{C}, 72.91 ; \mathrm{H}$, 6.12; N, 7.73. Found: C, 72.63; H, 6.00; N, 7.45.

7-(2-Methoxybenzyl)-4-(2-methoxyphenyl)-5,6-dihydrocyclopenta $[e][1,3]$-thiazin-2(3H)-imine (4). Yield: $79 \%$ from aqueous methanol; m.p.: $220-222{ }^{\circ} \mathrm{C}$; IR $\left(\mathrm{KBr}, \mathrm{cm}^{-1}\right): 3383,3205(\mathrm{NH}), 3066(\mathrm{CH}$ aromatic $)$, 2925, 2857 (CH aliphatic), $1592(\mathrm{C}=\mathrm{N}) ;{ }^{1} \mathrm{H}$ NMR (300 $\left.\mathrm{MHz}, \mathrm{DMSO}-d_{6}\right): \delta 10.00,9.94(\mathrm{~s}, 2 \mathrm{H}, 2 \mathrm{NH}), 7.54-6.46$ (m, 8H, Ar-H), 3.91 (s, 2H, Ar- $\mathrm{CH}_{2}$ ), 3.87, 3.74 (s, 6H, $\left.2 \mathrm{OCH}_{3}\right), 3.17-2.73\left(\mathrm{~m}, 4 \mathrm{H}, 2 \mathrm{CH}_{2}\right.$ cyclopentane). Anal. Calcd. for $\mathrm{C}_{22} \mathrm{H}_{22} \mathrm{~N}_{2} \mathrm{O}_{2} \mathrm{~S}$ (378.48): C, 69.81; H, 5.86; N, 7.40. Found: C, 70.12; H, 5.78; N, 7.14.

Synthesis of 4-(2-Methoxyphenyl)-8-[(2-methoxyphenyl)methylidene]-3,4,5,6,7,8-hexahydro-2(1H)-quinazolinethione (7)

A mixture of compound 6 (3.34 g, $0.01 \mathrm{~mol})$, thiourea $(0.76 \mathrm{~g}, 0.01 \mathrm{~mol})$ and sodium ethoxide $(0.02 \mathrm{~mol})$ [prepared of sodium $(0.46 \mathrm{~g})$ dissolved in absolute ethanol $(20 \mathrm{~mL})]$ in absolute ethanol $(30 \mathrm{~mL})$ was heated under reflux for $4 \mathrm{~h}$. The solid product obtained upon cooling was poured onto crushed ice and acidified with acetic acid, filtered off, dried and recrystallized from acetic acid. Yield: $85 \%$; m.p.: $165-167{ }^{\circ} \mathrm{C}$; IR $\left(\mathrm{KBr}, \mathrm{cm}^{-1}\right)$ : 3404, $3247(\mathrm{NH}), 3063$ (CH aromatic), 2933, $2832(\mathrm{CH}$ aliphatic), $1655(\mathrm{C}=\mathrm{N}) ; 1594(\mathrm{C}=\mathrm{C}), 1243(\mathrm{C}=\mathrm{S}) ;{ }^{1} \mathrm{H}$ NMR (300 MHz, DMSO- $\left.d_{6}\right): \delta 9.14,8.70(\mathrm{~s}, 2 \mathrm{H}, 2 \mathrm{NH})$, 7.31-6.89 (m, 9H, Ar-H + CH ethylenic), $5.19(\mathrm{~s}, 1 \mathrm{H}$, 
Ar- $\underline{\mathrm{CH}}), 3.81,3.79\left(\mathrm{~s}, 6 \mathrm{H}, 2 \mathrm{OCH}_{3}\right), 2.50-1.46(\mathrm{~m}, 6 \mathrm{H}$, $\mathrm{CH}_{2}$ cyclohexane). ${ }^{13} \mathrm{C}-\mathrm{NMR}\left(75 \mathrm{MHz}, \mathrm{DMSO}-d_{6}\right): \delta$ $22.25\left(\mathrm{CH}_{2}\right), 26.11\left(\mathrm{CH}_{2}\right), 26.63\left(\mathrm{CH}_{2}\right), 52.46(\mathrm{~N}-\mathrm{C}-\mathrm{C})$, $55.17\left(\mathrm{OCH}_{3}\right), 55.56\left(\mathrm{OCH}_{3}\right), 110.81,111.24,113.72$, $119.00,119.78,120.81,125.51,127.53,127.56,128.32$, $128.98,130.14,130.67 \quad(\mathrm{~N}-\underline{\mathrm{C}}=\mathrm{C}), 156.00 \quad(\mathrm{O}-\underline{\mathrm{C}}=\mathrm{C})$, $156.88(\mathrm{O}-\mathrm{C}=\mathrm{C}), 174.48(\mathrm{C}=\mathrm{S})$. Anal. Calcd. for $\mathrm{C}_{23} \mathrm{H}_{24} \mathrm{~N}_{2} \mathrm{O}_{2} \mathrm{~S}(392.51)$ : C, 70.38; H, 6.16; N, 7.14. Found: C, 70.03; H, 5.86; N, 6.83 .

Synthesis of 4-(2-Methoxyphenyl)-8-[(2-methoxyphenyl)methylidene]-3,4,5,6,7,8-hexahydro-2(1H)-quinazolinone (8)

A mixture of 7 (3.92 g, $0.01 \mathrm{~mol})$ and sodium hydroxide $(0.40 \mathrm{~g}, 0.01 \mathrm{~mol})$ was dissolved in DMF $(30 \mathrm{~mL})$. To this solution, $\mathrm{H}_{2} \mathrm{O}_{2}(0.02 \mathrm{~mol})$ was added drop wise with stirring at r.t. for $2 \mathrm{~h}$. The reaction mixture was neutralized by $\mathrm{HCl}$, and the precipitated solid was filtered off, dried and recrystallized from methanol.

Yield: $89 \%$; m.p.: $180-182{ }^{\circ} \mathrm{C}$; IR $\left(\mathrm{KBr}, \mathrm{cm}^{-1}\right)$ : 3407 (OH enolic); 3336, $3235(\mathrm{NH}), 3111,3067$ (CH aromatic), 2947, 2878 ( $\mathrm{CH}$ aliphatic), $1671(\mathrm{C}=\mathrm{O}), 1594$ $(\mathrm{C}=\mathrm{N}) ;{ }^{1} \mathrm{H}$ NMR $\left(300 \mathrm{MHz}, \mathrm{DMSO}-d_{6}\right): \delta 8.07$ (s, $2 \mathrm{H}$, 2NH), 7.28-6.82 (m, 9H, Ar-H + CH ethylenic), 5.19 (s, $1 \mathrm{H}, \mathrm{Ar}-\underline{\mathrm{CH}}), 3.80,3.78$ (s, 6H, 20CH $), 2.49-1.49$ (m, $6 \mathrm{H}, \mathrm{CH}_{2}$ cyclohexane). ${ }^{13} \mathrm{C}$ NMR (75 MHz, DMSO- $d_{6}$ ): $\delta$ $22.45\left(\mathrm{CH}_{2}\right), 25.93\left(\mathrm{CH}_{2}\right), 26.64\left(\mathrm{CH}_{2}\right), 52.35(\mathrm{~N}-\mathrm{C}-\mathrm{C})$, $55.71\left(\mathrm{OCH}_{3}\right), 55.56\left(\mathrm{OCH}_{3}\right), 110.83,110.98,111.24$, $118.99,119.75,120.74,125.87,127.36,127.56,128.13$, $128.62,128.97,130.68,131.58(\mathrm{~N}-\mathrm{C}=\mathrm{C}), 153.73(\mathrm{C}=\mathrm{O})$, $156.20(\mathrm{O}-\mathrm{C}=\mathrm{C}), 156.90(\mathrm{O}-\mathrm{C}=\mathrm{C})$. Anal. Calcd. for $\mathrm{C}_{23} \mathrm{H}_{24} \mathrm{~N}_{2} \mathrm{O}_{3}$ (376.44): C, 73.38; H, 6.43; N, 7.44. Found: C, 73.03; H, 6.53; N, 7.63.

Synthesis of 8-(2-Methoxybenzylidene)-4-(2-methoxyphenyl)-5,6,7,8-tetrahydroquinazoline (9)

To a solution of $7(3.92 \mathrm{~g}, 0.01 \mathrm{~mol})$ in acetic acid $(20 \mathrm{~mL})$, $\mathrm{H}_{2} \mathrm{O}_{2}(0.02 \mathrm{~mol})$ was added drop wise at r.t. with stirring. Furthermore, the reaction mixture was stirred at r.t. for $3 \mathrm{~h}$. The separated solid was collected by filtration, washed with water, dried and recrystallized from methanol.

Yield: $65 \%$; m.p.: $136-138{ }^{\circ} \mathrm{C}$; IR $\left(\mathrm{KBr}, \mathrm{cm}^{-1}\right)$ : 2924, 2856 (aliphatic CH), $1600(\mathrm{C}=\mathrm{N}) ;{ }^{1} \mathrm{H}$ NMR (300 $\mathrm{MHz}$, DMSO- $\left.d_{6}\right): \delta 8.20-6.96(\mathrm{~m}, 10 \mathrm{H}, \mathrm{Ar}-\mathrm{H}+\mathrm{CH}$ ethylenic), 3.81, $3.72\left(\mathrm{~s}, 6 \mathrm{H}, 2 \mathrm{OCH}_{3}\right), 2.72-0.74(\mathrm{~m}, 6 \mathrm{H}$, $\mathrm{CH}_{2}$ cyclohexane). Anal. Calcd for $\mathrm{C}_{23} \mathrm{H}_{22} \mathrm{~N}_{2} \mathrm{O}_{2}$ (358.43): C, 77.07; H, 6.19; N, 7.82. Found C, 76.79; H, 5.98; N, 7.59 .

Synthesis of 2-Hydrazino-8-(2-methoxybenzyl)-4-(2methoxyphenyl)-1,5,6,7-tetrahydroquinazoline (10)

A mixture of 7 (3.92 g, $0.01 \mathrm{~mol})$ and hydrazine hydrate $(0.015 \mathrm{~mol})$ in pyridine $(20 \mathrm{~mL})$ was refluxed for $5 \mathrm{~h}$. The reaction mixture was cooled and neutralized with dilute $\mathrm{HCl}$. The separated solid was filtered off, dried and recrystallized from methanol.
Yield: $54 \%$; m.p.: $130-132{ }^{\circ} \mathrm{C}$; IR $\left(\mathrm{KBr}, \mathrm{cm}^{-1}\right)$ : 3400-3264 (NH, $\left.\mathrm{NH}_{2}\right), 2926-2856\left(\mathrm{CH}\right.$ aliphatic); ${ }^{1} \mathrm{H}$ NMR (300 MHz, DMSO- $\left.d_{6}\right): \delta 9.13,8.68(\mathrm{~s}, 2 \mathrm{H}, 2 \mathrm{NH}$, $\mathrm{D}_{2} \mathrm{O}$ exchangeable), 7.32-6.89 (m, 8H, Ar-H), 5.18 (s, $2 \mathrm{H}, \mathrm{NH}_{2}, \mathrm{D}_{2} \mathrm{O}$ exchangeable), 3.84 (s, 2H, Ar- $\mathrm{CH}_{2}$ ), 3.81, $3.78\left(\mathrm{~s}, 6 \mathrm{H}, 2 \mathrm{OCH}_{3}\right), 2.45-1.05\left(\mathrm{~m}, 6 \mathrm{H}, \mathrm{CH}_{2}\right.$ cyclohexane); ${ }^{13} \mathrm{C}$ NMR $\left(100 \mathrm{MHz}\right.$, DMSO- $\left.d_{6}\right): \delta 22.77\left(\mathrm{CH}_{2}\right)$, $26.64\left(\mathrm{CH}_{2}\right), 27.11\left(\mathrm{CH}_{2}\right), 42.64\left(\mathrm{Ar}-\mathrm{CH}_{2}\right), 52.91,55.57$ $\left(\mathrm{OCH}_{3}\right), 56.07\left(\mathrm{OCH}_{3}\right), 111.31,111.75,114.31,119.55$, $120.29,121.33,126.00,128.02,128.05,128.85,129.46$, $129.52,130.66,131.20\left(\mathrm{C}-\mathrm{NHNH}_{2}\right), 156.47$ (Ar-C), 157.38 (Ar-C), $174.96(\mathrm{C}=\mathrm{N})$. Anal. Calcd. for $\mathrm{C}_{23} \mathrm{H}_{26} \mathrm{~N}_{4} \mathrm{O}_{2}$ (390.48): C, 70.75; H, 6.71; N, 14.35. Found: C, 70.51; H, 6.91; N, 14.63.

Synthesis of 5-(2-Methoxyphenyl)-9-[(2-methoxyphenyl)methylidene]-6,7,8,9-tetrahydro-5 $H$ - $[1,3]$ thiazolo[3,2-a]quinazolin-1 $(2 H)$-one (11)

A mixture of chalcone 6 (3.34 g, $0.01 \mathrm{~mol})$, 2-amino-1,3thiazol-4(5H)-one (1.16 g, $0.01 \mathrm{~mol})$ and conc. HC$1(1.5 \mathrm{~mL})$ in ethanol $(30 \mathrm{~mL})$ was refluxed for $5 \mathrm{~h}$. The reaction mixture was left to cool at room temperature. The precipitated solid was filtered off, dried and recrystallized from acetic acid.

Yield 63\%; m.p.: > $360{ }^{\circ} \mathrm{C}$; IR $\left(\mathrm{KBr}, \mathrm{cm}^{-1}\right): 3411$ (OH enolic), 2927-2859 (CH aliphatic), $1696(\mathrm{C}=\mathrm{O})$, $1618(\mathrm{C}=\mathrm{N}) ;{ }^{1} \mathrm{H}$ NMR $\left(300 \mathrm{MHz}, \mathrm{DMSO}-d_{6}\right): \delta$ 7.95-6.93 (m, 9H, Ar-H + CH ethylenic), $4.50(\mathrm{~s}, 1 \mathrm{H}$, Ar- $\mathrm{CH}), 4.14$ (d, $2 \mathrm{H}, J=0.6 \mathrm{~Hz}, \mathrm{CH}_{2}$ of thiazole), 3.83, $3.80\left(\mathrm{~s}, 6 \mathrm{H}, 2 \mathrm{OCH}_{3}\right), 2.86-1.70\left(\mathrm{~m}, 6 \mathrm{H}, \mathrm{CH}_{2}\right.$ cyclohexane). Anal. Calcd. for $\mathrm{C}_{25} \mathrm{H}_{24} \mathrm{~N}_{2} \mathrm{O}_{3} \mathrm{~S}$ (432.53): C, 69.42; H, 5.59; N, 6.48. Found: C, 69.12; H, 5.45; N, 6.64.

General Procedure for the Synthesis of Chromene Derivatives 13 and 16

A mixture of 6 (3.34 g, $0.01 \mathrm{~mol})$, acetyl acetone and/or malononitrile $(0.01 \mathrm{~mol})$ and a few drops of TEA in dimethyl formamide $(30 \mathrm{~mL})$ was heated under reflux for $20 \mathrm{~h}$. The solid product obtained upon cooling, poured into ice cold water and acidified by acetic acid, filtered off, dried, and recrystallized from the proper solvent gave compounds 13 and $\mathbf{1 6}$, respectively.

1-[8-(2-Methoxybenzyl)-4-(2-methoxyphenyl)-2methyl-6,7-dihydro-5H-chromen-3-yl]-1-ethanone (13). Yield: $69 \%$ from aqueous methanol; m.p.: 170-173 ${ }^{\circ} \mathrm{C}$; IR ( $\left.\mathrm{KBr}, \mathrm{cm}^{-1}\right): 3064(\mathrm{CH}$ aromatic), 2925, $2851(\mathrm{CH}$ aliphatic), $1660(\mathrm{C}=\mathrm{O}), 1600(\mathrm{C}=\mathrm{C}) ;{ }^{1} \mathrm{H}$ NMR $(300 \mathrm{MHz}$, DMSO- $\left.d_{6}\right): \delta 7.38-6.64(\mathrm{~m}, 8 \mathrm{H}, \mathrm{Ar}-\mathrm{H}), 3.88\left(\mathrm{~s}, 2 \mathrm{H}, \mathrm{CH}_{2}\right.$ benzylic), 3.84, $3.71\left(\mathrm{~s}, 6 \mathrm{H}, 2 \mathrm{OCH}_{3}\right), 2.49(\mathrm{~s}, 3 \mathrm{H}$, $\left.\mathrm{COCH}_{3}\right), 2.46\left(\mathrm{~s}, 3 \mathrm{H}, \mathrm{CH}_{3}\right), 2.79-1.23\left(\mathrm{~m}, 6 \mathrm{H}, \mathrm{CH}_{2}\right.$ cyclohexane). Anal. Calcd. for $\mathrm{C}_{27} \mathrm{H}_{28} \mathrm{O}_{4}$ (416.50): C, 77.86; H, 6.78. Found: C, 77.58; H, 6.67.

2-Amino-4-(2-methoxyphenyl)-8-[(2-methoxyphenyl) methylidene]-5,6,7,8-tetrahydro-4H-chromene-3-car- 
bonitrile (16). Yield: $73 \%$ from methanol; m.p.: 280-282 ${ }^{\circ} \mathrm{C}$; IR $\left(\mathrm{KBr}, \mathrm{cm}^{-1}\right)$ : 3340-3223 $\left(\mathrm{NH}_{2}\right), 3089$ (CH aromatic), 2935 ( $\mathrm{CH}$ aliphatic), $2205(\mathrm{CN}), 1664$ $(\mathrm{C}=\mathrm{N}), 1593(\mathrm{C}=\mathrm{C}) ;{ }^{1} \mathrm{H}$ NMR $\left(300 \mathrm{MHz}, \mathrm{DMSO}-d_{6}\right): \delta$ 8.00 (s, 2H, $\left.\mathrm{NH}_{2}\right), 7.43-6.20(\mathrm{~m}, 9 \mathrm{H}, \mathrm{Ar}-\mathrm{H}+\mathrm{CH}$ ethylenic), $4.08(\mathrm{~s}, 1 \mathrm{H}, \mathrm{Ar}-\mathrm{CH}), 3.78,3.76\left(\mathrm{~s}, 6 \mathrm{H}, 2 \mathrm{OCH}_{3}\right)$, 2.82-1.50 (m, 6H, $\mathrm{CH}_{2}$ cyclohexane); ${ }^{13} \mathrm{C}$ NMR (100 MHz, DMSO- $\left.d_{6}\right): \delta 28.38\left(\mathrm{CH}_{2}\right), 28.99\left(\mathrm{CH}_{2}\right), 32.96$ $\left(\mathrm{CH}_{2}\right), 33.95$ ( Ar- $\left.\mathrm{CH}\right), 34.54,55.79,77.18,85.81$, 111.64, 113.72, 114.40, 118.33, 120.91, 124.90, 126.21, 126.49, 128.56, 128.78, 131.04, 156.31 (Ar-C), 158.27 (C-NH$), 164.49$ (Ar-C). Anal. Calcd. for $\mathrm{C}_{25} \mathrm{H}_{24} \mathrm{~N}_{2} \mathrm{O}_{3}$ (400.46): C, 74.98; H, 6.04; N, 7.00. Found: C, 74.69; H, $5.95 ; \mathrm{N}, 6.74$.

\section{General Procedure for the Synthesis of Compounds 17,21 and 23}

A mixture of chalcone 6 (3.34 g, $0.01 \mathrm{~mol}$ ), ethyl cyanoacetate, cyanoacetamide and/or $N$-phenyl cyanoacetamide $(0.01 \mathrm{~mol})$ and sodium ethoxide $(0.02 \mathrm{~mol})$ [prepared of $0.46 \mathrm{~g}$ sodium dissolved in ethanol absolute $(20 \mathrm{~mL})]$ in ethanol $(30 \mathrm{~mL})$ was refluxed for $3 \mathrm{~h}$. The reaction mixture was cooled, poured into ice cold water and neutralized with acetic acid. The precipitated solid was filtered off, dried to give crude material of $\mathbf{1 7}, \mathbf{2 1}$ and $\mathbf{2 2}$, respectively. The crude product 22 in $20 \mathrm{~mL}$ aqueous $\mathrm{NaOH}(10 \%)$ was heated under reflux for $1 \mathrm{~h}$. The resultant solution was cooled, diluted with ice cold water and acidified with HC1. The precipitated solid was filtered off, dried to give compound 23.

4-(2-Methoxyphenyl)-8-[(2-methoxyphenyl)methylidene]-2-oxo-3,4,5,6,7,8-hexahydro- $2 H$-chromene-3-carbonitrile (17). Yield: 78\% from methanol; m.p.: 148-150 ${ }^{\circ} \mathrm{C}$; IR ( $\left.\mathrm{KBr}, \mathrm{cm}^{-1}\right)$ : 3432 (OH enolic), 3055 ( $\mathrm{CH}$ aromatic), 2927-2846 (CH aliphatic), $2197(\mathrm{CN}), 1674(\mathrm{C}=\mathrm{O})$, $1594(\mathrm{C}=\mathrm{C}) ;{ }^{1} \mathrm{H}$ NMR $\left(300 \mathrm{MHz}, \mathrm{DMSO}-d_{6}\right): \delta$ 7.80-6.97 (m, 9H, Ar-H + CH ethylenic), 3.83, 3.78 (dd, $2 \mathrm{H}, J=9.0 ; 6.6 \mathrm{~Hz}, 2 \mathrm{CH}), 3.77,3.72\left(\mathrm{~s}, 6 \mathrm{H}, 2 \mathrm{OCH}_{3}\right)$, 2.79-1.56 (m, 6H, $\mathrm{CH}_{2}$ cyclohexane). Anal. Calcd. for $\mathrm{C}_{25} \mathrm{H}_{23} \mathrm{NO}_{4}$ (401.54): C, 74.79; H, 5.77; N, 3.49. Found: C, 74.47; H, 5.47; N, 3.14 .

8-(2-Methoxybenzyl)-4-(2-methoxyphenyl)-2-oxo1,2,5,6,7,8-hexahydro-3-quinolinecarbonitrile (21). Yield: $75 \%$ from acetic acid; m.p.: $265-267{ }^{\circ} \mathrm{C}$; IR (KBr, $\left.\mathrm{cm}^{-1}\right): 3468((\mathrm{NH}), 3011(\mathrm{CH}$ aromatic $), 2932,2837(\mathrm{CH}$ aliphatic), $2223(\mathrm{CN}), 1635(\mathrm{C}=\mathrm{O})$; ${ }^{1} \mathrm{H}$ NMR $(300 \mathrm{MHz}$, DMSO- $\left.d_{6}\right): \delta 9.82(\mathrm{~s}, 1 \mathrm{H}, \mathrm{NH}), 7.59-6.83(\mathrm{~m}, 8 \mathrm{H}, \mathrm{Ar}-\mathrm{H})$, $4.31\left(\mathrm{~d}, 2 \mathrm{H}, J=4.2 \mathrm{~Hz}, \mathrm{Ar}-\mathrm{CH}_{2}\right), 3.82,3.72(\mathrm{~s}, 6 \mathrm{H}$, $\left.2 \mathrm{OCH}_{3}\right), 2.45-1.55\left(\mathrm{~m}, 7 \mathrm{H}, \mathrm{CH}\right.$ cyclohexane). ${ }^{13} \mathrm{C} \mathrm{NMR}$ (75 MHz, DMSO- $\left.d_{6}\right): \delta 22.13\left(\mathrm{CH}_{2}\right), 25.06\left(\mathrm{CH}_{2}\right), 26.48$ $\left(\mathrm{CH}_{2}\right), 55.40\left(\mathrm{OCH}_{3}\right), 55.65\left(\mathrm{OCH}_{3}\right), 111.13,111.72$, 115.91, 119.97, 120.76, 124.19, 124.69, 127.40, 128.80, $129.68,130.10,130.87,155.20 \quad(\mathrm{O}-\underline{\mathrm{C}}=\mathrm{C})), 157.33$ $(\mathrm{O}-\underline{\mathrm{C}}=\mathrm{C})), 160.18(\mathrm{C}=\mathrm{O})$. Anal. Calcd. for $\mathrm{C}_{25} \mathrm{H}_{24} \mathrm{~N}_{2} \mathrm{O}_{3}$
(400.47): C, 74.98; H, 6.04; N, 7.00. Found: C, 75.33; H, $5.95 ; \mathrm{N}, 6.78$.

4-(2-Methoxyphenyl)-8-[(2-methoxyphenyl)methylidene]-2-oxo-1,2,3,4,5,6,7,8-octahydro-3-quinolinecarboxylic acid (23). Yield: $67 \%$ from benzene; m.p.: 238-240 ${ }^{\circ} \mathrm{C}$; IR $\left(\mathrm{KBr}, \mathrm{cm}^{-1}\right.$ ): 3432 (OH broad), 2924, 2854 (CH aliphatic), 1707, $1628(\mathrm{C}=\mathrm{O}) ;{ }^{1} \mathrm{H}$ NMR (300 $\left.\mathrm{MHz}, \mathrm{DMSO}-d_{6}\right): \delta 12.11$ (s, $\left.1 \mathrm{H}, \mathrm{OH}\right), 9.52(\mathrm{~s}, 1 \mathrm{H}, \mathrm{NH})$, 7.56-6.88 (m, 9H, Ar-H + CH ethylenic), $4.92(\mathrm{~d}, 1 \mathrm{H}, J=$ $3 \mathrm{~Hz}, \mathrm{CH}-\mathrm{CO}$ ), 3.77 (d, 1H, $J=4 \mathrm{~Hz}, \mathrm{Ar}-\mathrm{CH}), 3.74,3.70$ (s, $\left.6 \mathrm{H}, 2 \mathrm{OCH}_{3}\right), 2.73-1.23\left(\mathrm{~m}, 6 \mathrm{H}, \mathrm{CH}_{2}\right.$ cyclohexane). Anal. Calcd. for $\mathrm{C}_{25} \mathrm{H}_{25} \mathrm{NO}_{5}$ (419.47): C, 71.58; H, 6.01; N, 3.34. Found: C, 71.93; H, 5.86; N, 3.66.

\section{2. Antitumor Activity Tests}

Reagents: Fetal bovine serum (FBS) and L-glutamine, were from Gibco Invitrogen Co. (Scotland, UK). RPMI-1640 medium was from Cambrex (New Jersey, USA). Dimethyl sulfoxide (DMSO), doxorubicin, penicillin, streptomycin and sulforhodamine B (SRB) were from Sigma Chemical Co. (Saint Louis, USA).

Cell cultures: Three human tumor cell lines, MCF-7 (breast adenocarcinoma), NCI-H460 (non-small cell lung cancer), and SF-268 (CNS cancer) were used. MCF-7, XF498, colon; A549, ovarian; HCT15, stomach; was obtained from the European Collection of Cell Cultures (ECACC, Salisbury, UK), NCI-H460, SF-268 and normal fibroblast cells (WI 38) were kindly provided by the National Cancer Institute (NCI, Cairo, Egypt). They grow as a monolayer and routinely maintained in RPMI1640 medium supplemented with $5 \%$ heat inactivated FBS, $2 \mathrm{mM}$ glutamine and antibiotics (penicillin 100 $\mathrm{U} / \mathrm{mL}$, streptomycin $100 \mu \mathrm{M}$ ), at $37{ }^{\circ} \mathrm{C}$ in a humidified atmosphere containing $5 \% \mathrm{CO}_{2}$. Exponentially growing cells were obtained by plating $1.5 \times 10^{5}$ cells $/ \mathrm{mL}$ for MCF-7, NCI-H460 and SF-268 and $0.75 \times 10^{4}$ cells $/ \mathrm{mL}$ followed by $24 \mathrm{~h}$ of incubation. The effect of the vehicle solvent (DMSO) on the growth of these cell lines was evaluated in all the experiments by exposing untreated control cells to the maximum concentration $(0.5 \%)$ of DMSO used in each assay.

\section{Conclusion}

A series of novel condensed pyrimidine, pyran and pyridine derivatives were synthesized and assayed for their antitumor activity against three human cell lines namely MCF-7, NCI-H460 and SF-268. The activity comparison and the structure correlation of the tested compounds had shown that these potencies paralleled the electron withdrawing powers of the substituent groups. Hence, the higher cytotoxcity of compounds $\mathbf{1 4}$ and $\mathbf{1 5}$ was attributed to the presence of the electronegative cyano group. 


\section{Acknowledgements}

The authors thank Prof. Dr. Rafat M. Mohareb for running the $\mathrm{IC}_{50}$ assays and for offering the needed facilities and Prof. Dr. Jamal Abdel Lateif Ahmed for assistance in the early stages of this program.

\section{Supplementary Material}

Copies of the IR, ${ }^{1} \mathrm{H},{ }^{13} \mathrm{C}$ NMR spectra and antitumor evaluations of the new compounds are available on the Journal's website.

\section{References}

1. S. Chitra, D. Devanathan, K. Pandiarajan, Eur. J. Med. Chem. 2009, 45, 1-5.

2. N. M. Hamada, N. Y. Megally, Molecules 2015, 20, 1046810486. http://dx.doi.org/10.3390/molecules200610468

3. P. G. Baraldi, S. Manfredini, R. Romagnoli, L. Stevanato, A. N. Zaid, R. Manservigi, Nucleos. Nucleot. Nucl. 1998, 17, 2165-2173. http://dx.doi.org/10.1080/07328319808004307

4. R. Sawant, V. Sarode, Iran. J. pharma. Res. 2011, 10(4), 733-739.

5. M. M. Kamel, N. Y. Megally, Eur. J. Med. Chem. 2014, 86, 75-80. http://dx.doi.org/10.1016/j.ejmech.2014.08.047

6. V. K. Narayanaswamy, S. K. Nayak, M. Pillay, R. Prasanna, Y. M. Coovadia, B. Odhav, Chem. Biol. Drug Des. 2013, 81, 219-227. http://dx.doi.org/10.1111/cbdd.12065

7. O. I. El-Sabbagh, S. Mostafa, H. A. Abdel-Aziz, H. S. Ibrahim, M. M. Elaasser, Arch. Pharm. Chem. Life Sci. 2013, 346, 688-698.

http://dx.doi.org/10.1002/ardp.201300193

8. M. M. Elaasser, M. M. Abdel-Aziz, R. A. El-Kassas, J. Microbiol. Biotech. Res. 2011, 1(4), 5-17.

9. N. J. P. Subhashini, J. Amanaganti, L. Boddu, P. A. Nagarjuna, J. Chem. Pharm. Res. 2013, 5(1), 140-146.

10. R. Al-Salahi, I. Alswaidan, H. A. Ghabbour, E. Ezzeldin, M. Elaasser, M. Marzouk, Molecules 2015, 20, 5099-5111. http://dx.doi.org/10.3390/molecules20035099

11. M. M. Youssef, M. A. Amin, Molecules 2012, 17, 96529667. http://dx.doi.org/10.3390/molecules17089652

12. M. M. Ramiz, W. A. El-Sayed, E. Hagag, A. A. AbdelRahman, J. Heterocycl. Chem. 2011, 48, 1028-1038. http://dx.doi.org/10.1002/jhet.686

13. E. R. Kotb, N. M. Yousif, M. A. M. Salama, M. M. Ali, H. S. Khalaf, RJPBCS 2015, 6(1), 516-528.

14. A. A. Fayed, A. F. El-Farargy, N. M. Yousif, F. A. Gad, A. Kalmouch, Der Pharma Chemica 2015, 7(2), 316-322.

15. A. E. Rashad, A. H. Shamroukh, M. A. El-Hashash, A. F. ElFarargy, N. M. Yousif, M. A. Salama, A. Mostafa, M. El-Shahat, J. Heterocycl. Chem. 2012, 49, 1130-1135. http://dx.doi.org/10.1002/jhet.966
16. I. W. Cheney, S. Yan, T. Appleby, H. Walker, T. Vo, N. Yao, R. Hamatake, Z. Hong, J. Z. Wu, Bioorg. Med. Chem. Lett. 2007, 17, 1679-1683. http://dx.doi.org/10.1016/j.bmcl.2006.12.086

17. P. Gary, J.-W. Soh, Y. Mao, M.-G. Kim, R. Pamukcu, H. Li, W. J. Thompson, I. B. Weinstein, Clin. Cancer Res. 2000, 6, 4136-4141.

18. J. Cheng, J. P. Grande, Exp. Biol. Med. 2007, 232, 38-51.

19. Y.-L. Zhu, S.-L. Huang, Y.-J. Pan, Eur. J. Org. Chem. 2005, 2354-2367. http://dx.doi.org/10.1002/ejoc.200400845

20. S. Rahmani, A. Amoozadeh, E. Kolvari, Catalysis Communications 2014,, 184-188.

http://dx.doi.org/10.1016/j.catcom.2014.07.002

21. A. Amoozadeh, S. Rahmani, F. Nemati, Heterocycl. Commun. 2013, 19(1), 69-73.

http://dx.doi.org/10.1515/hc-2012-0157

22. C. Mukhopadhyay, A. Datta, ), 438-449. http://dx.doi.org/10.1080/00397911.2011.602497

23. M. D. Wendt, C. Sun, A. Kunzer, D. Sauer, K. Sarris, E. Hoff, L. D. Yu, G. Nettesheim, J. Chen, S. Jin, Bioorg. Med. Chem. Lett. 2007, 17, 3122-3129.

http://dx.doi.org/10.1016/j.bmcl.2007.03.042

24. N. A. Aqui, R. H. Vonderheide, Cancer Biol. Ther. 2008, 7 , 1888-1889. http://dx.doi.org/10.4161/cbt.7.12.7219

25. G. Ambrosini, C. Adida, D. C. Altieri, Nat. Med. 1997, 3, 917-921. http://dx.doi.org/10.1038/nm0897-917

26. S. M. Riyadh, Molecules 2011, 16, 1834-1853. http://dx.doi.org/10.3390/molecules16021834

27. M. Abbas, S. M. Riyadh, M. A. Abdallah, S. M. Gomha, $J$. Heterocycl. Chem., 2006, 43, 935-942. http://dx.doi.org/10.1002/jhet.5570430419

28. S. M. Gomha, S. M. Riyadh, Molecules 2011, 16, 82448256. http://dx.doi.org/10.3390/molecules 16108244

29. A. E. Rashad, A. H. Shamroukh, N. M. Yousif, M. A. Salama, H. S. Ali, M. M. Ali, A. E. Mahmoud, M. El-Shahat, Arch. Pharm. Chem. Life Sci. 2012, 345, 729-738. http://dx.doi.org/10.1002/ardp.201200119

30. E. Abdelghani, Heterocycles 2001, 55(12), 2413-2421. http://dx.doi.org/10.3987/COM-01-9348

31. E. Abdelghani, J. Chem. Res. 1999, (S), 174-175; (M), 11351150.

32. M. G. Assy, E. Abdelghani, Pol. J. Chem. 1995, 69, 685-687.

33. M. G. Assy, H. H. Sayed, A. H. Moustafa, M. N. Yousif, M. A. El-Hallim, Phosphorus Sulfur 2008, 183, 2318-2329. http://dx.doi.org/10.1080/10426500801963590

34. E. Abdelghani, S. A. Said, M. G. Assy, A. M. Abdel Hamid, J. Iran. Chem. Soc. 2015, 12, 1809-1817.

35. F. J. Smit, R. A. van Biljon, L.-M. Birkholtz, D. D. N'Da, Eur. J. Med. Chem. 2015, 90, 33-44. http://dx.doi.org/10.1016/j.ejmech.2014.11.016

36. P. Kaswan, K. Pericherla, D. Purohit, A. Kumar, Tetrahedron Lett. 2015, 56, 549-553. http://dx.doi.org/10.1016/j.tetlet.2014.11.121

37. N. Y. Megally Abdo, Acta Chim. Slov. 2015, 62, 168-180. http://dx.doi.org/10.17344/acsi.2014.867

38. M. M. Kamel, Acta Chim. Slov. 2015, 62, 136-151. 
http://dx.doi.org/10.17344/acsi.2014.828

39. L. Wang, G. Chen, X. Lu, S. Wang, S. Han, Y. Li, G. Ping, X. Jiang, H. Li, J. Yang, C. Wu, Eur. J. Med. Chem. 2015, 89, 88-97. http://dx.doi.org/10.1016/j.ejmech.2014.10.036

40. V. Kanagarajan, M. Gopalakrishnan, Pharm. Chem. J. 2011, 45(4), 248-256.

http://dx.doi.org/10.1007/s11094-011-0611-1

41. E. Campaigne, Comprehen. Heter. Chem. 1984, 4, 863-984.

42. P. Skehan, R. Storeng, D. Scudiero, A. Monks, J. McMahon, D. Vistica, J. T. Warren, H. Bokesch, S. Kenny, M. R. Boyd,
J. Natl. Cancer Inst. 1990, 82, 1107-1112. http://dx.doi.org/10.1093/jnci/82.13.1107

43. A. Monks, D. Scudiero, P. Skehan, R. Shoemaker, R. Storeng, K. Paul, D. Vistica, C. Hose, J. Langley, P. Cronise, A. Vaigro-Wolff, M. Gray-Goodr, H. Campbell, J. Mayo, J. M. Boyd, J. Natl. Cancer Inst. 1991, 83, 757-766. http://dx.doi.org/10.1093/jnci/83.11.757

44. M. M. Al-Arab, F. S. Al-Saleh, S. M. Mayoof, J. Heterocycl. Chem. 1998, 35, 1473-1476.

http://dx.doi.org/10.1002/jhet.5570350643

\section{Povzetek}

$\mathrm{Z}$ »one-pot « reakcijo med ciklopentanonom, ustreznim aromatskimi aldehidom ( $o$-anisaldehid) in različnimi sečninami (sečnina, gvanidin, tiosečnina) smo sintetizirali serijo pirimidinskih in tiazinskih derivatov. Pri cikloadiciji reagentov, ki vsebujejo aktivno metilensko skupino (acetil aceton, malononitril, etil cianoacetat, cianoacetamid in $N$-fenil cianoacetamid), z 2,6-bis(2-metoksibenziliden)cikloheksanonom pod bazičnimi pogoji nastanejo kromenski in kinolinski derivati. Za nekatere nove spojine smo preučili tudi njihove antitumorne lastnosti proti trem človeškim rakastim celičnim linijam, in sicer MCF-7, NCI-H460 in SF-268, ter ugotovili zmerno dobre aktivnosti glede na pozitivno kontrolo doksorubicin. 